Hydrology and Earth System Sciences, 5(3), 351-366 (2001) @ C EGS

\title{
Chemical trends at lakes and streams in the UK Acid Waters Monitoring N etwork, 1988-2000: Evidence for recent recovery at a national scale
}

\author{
C.D. Evans ${ }^{1}$ and D.T. Monteith ${ }^{2}$ \\ ${ }^{1}$ Centre for Ecology and Hydrology. Wallingford, Oxon., OX10 8BB, UK \\ ${ }^{2}$ Environmental Change Research Centre, University College London, 26 Bedford Way, London, WC1H 0AP, UK
}

Email for corresponding author: cev@ceh.ac.uk

\section{Abstract}

\begin{abstract}
A detailed trend analysis of 12 years of data (1988-2000) for 22 surface waters in acid-sensitive regions of the United Kingdom, in which individual site data have been combined to identify national-scale trends, has shown strong common patterns of temporal variation. Results suggest a widespread reduction in sulphate concentrations, hydrogen ion and inorganic aluminium species, and increases in acid neutralising capacity. Many chemical changes have not been linear. However, the first five years were characterised by high concentrations of marine ions and relatively stable pollutant sulphate concentrations and the remaining period by lower concentrations of marine ions and declining sulphate. Genuine 'recovery', in terms of declining acidity in response to reduced anthropogenic sulphur deposition is only apparent, therefore, for the latter part of the monitoring period. Reductions in calcium concentrations appear to have partially offset the influence of sulphate reductions on acidity, as have increases in organic acidity associated with strong and widespread rising trends in dissolved organic carbon. Fluctuations in a number of climatic factors over the monitoring period have led to significant inter-annual variability in nitrate, which exhibits little longterm trend, marine ions and acidity, emphasising the need for long monitoring periods if underlying trends are to be correctly identified.
\end{abstract}

Keywords: acidification, recovery, long-term trends, climate, Dissolved Organic Carbon, United Kingdom Acid Waters Monitoring Network

\section{Introduction}

Acidification of soils and waters results from the emission, transportation and deposition of sulphur $(\mathrm{S})$ and nitrogen (N) compounds, primarily from fossil fuel burning. Detrimental effects of 'acid rain' were first documented in the Pennines, Northern England, following the onset of industrialisation during the mid- $19^{\text {th }}$ century and have since been observed across many areas of the UK. The analysis of diatom fossils in lake sediment cores has provided evidence of long-term freshwater acidification, with a progressive change from acid-sensitive to acid-tolerant species over the last 150 years (Battarbee et al., 1988). UK (S) emissions peaked during the 1970s and have since declined in response to changes in the industrial sector and to a series of emission control agreements, most recently the Multi-Pollutant Multi-Effect Protocol, signed in
Gothenburg in 1999. As a result, UK S emissions are now around $75 \%$ lower than their 1970s peak, whilst nitrogen oxide $\left(\mathrm{NO}_{\mathrm{x}}\right)$ emissions have fallen by around $30 \%$, primarily since 1990, and reduced nitrogen $\left(\mathrm{NH}_{\mathrm{y}}\right)$ emissions (mainly from agriculture) have remained approximately constant (NEGTAP, 2001).

High quality monitoring of impacted ecosystems is vital to determine whether reductions in the emissions of acidifying pollutants are leading to the desired improvements in the water quality of damaged systems and also to develop the scientific understanding and predictive models used to support decision making on future emissions reductions. In the UK, monitoring during the 1970s and early 1980s was limited to local programmes in a few areas (e.g. Harriman et al., 2001; Helliwell et al., 2001). Co-ordinated national monitoring began in 1988 with the establishment of the UK 
Acid Waters Monitoring Network (AWMN) (Patrick et al., 1995), which provides a regular and controlled programme of chemical, biological and hydrological measurements across a representative range of 22 acid-sensitive waters. A recent report (Monteith and Evans, 2000) presented a detailed analysis of long-term trends over the first ten years of monitoring. During this period, relatively few sites exhibited clear signs of chemical recovery due to a number of factors. Firstly, it appeared that more remote western areas of the UK, where most sites are located, had experienced smaller reductions in $\mathrm{S}$ deposition than southern and eastern areas closer to emissions sources. Secondly, the monitoring period coincided with a period of major climatic variation linked to the North Atlantic Oscillation (NAO), an approximately decadal cycle influencing winter weather patterns in the UK (Hurrell, 1995). Warm, stormy winters in the early part of the record led to a combination of increased rainfall and marine ion deposition, and, therefore, to elevated concentrations of sodium $(\mathrm{Na})$, chloride $(\mathrm{Cl})$ and the marine component of sulphate $\left(\mathrm{SO}_{4}\right)$ at this time. $\mathrm{A}$ combination of dilution by high rainfall, and the displacement of hydrogen $(\mathrm{H})$ and aluminium $(\mathrm{Al})$ from soil exchange sites by marine base cations (the 'sea-salt effect'; Wright et al., 1988; Langan, 1989) also led to naturally acid conditions during this period (Evans et al., 2001a). Cold winters, particularly that of $1995 / 96$, are thought to have increased nitrate $\left(\mathrm{NO}_{3}\right)$ losses from catchment soils (Monteith et al., 2000), again obscuring the link between anthropogenic deposition inputs and runoff chemistry.

Two additional years of data (April 1998 - March 2000) were included in an analysis of temporal changes at a subset of six unforested mountain lakes in the AWMN by Evans and Monteith (2001). These lakes, with relatively stable short-term chemistry and minimal local influences, were considered most likely to show clear responses to anthropogenic deposition reductions and/or longer-term climatic changes. Results showed that the six lakes exhibited similar chemical changes over time and suggested that anthropogenic $\mathrm{SO}_{4}$ concentrations have begun to fall in recent years. For the present study, the analysis of trends over the 12 year period, and the techniques developed for the analysis of mountain lake sites, are extended to all lakes and streams in the AWMN. The aims of this analysis are: (a) to determine whether the apparent onset of chemical recovery observed at a subset of lakes has occurred elsewhere in the network; (b) to identify the extent to which patterns of temporal change are consistent at the national scale; and (c) to consider the extent to which chemical changes in other solutes have either reduced or obscured recovery from acidification in response to falling $\mathrm{S}$ deposition.

\section{Study sites}

The AWMN consists of 11 lakes and 11 streams in Scotland, England, Wales and Northern Ireland. The majority are located in western and northern areas, reflecting the distribution of acid-sensitive geology within the UK (Fig. 1). Streams have been sampled monthly, and lakes quarterly, for a range of chemical determinands over a 12 year period. Site characteristics vary widely, with minimum altitudes ranging from $10 \mathrm{~m}$ to $785 \mathrm{~m}$, catchment areas from 50 to $1300 \mathrm{ha}$, and soils from thin alpine podzols to deep blanket peats (Table 1). Land-use at most sites is restricted to lowintensity moorland grazing with five catchments containing significant areas of commercial coniferous forestry.

Water chemistry varies within the network (Table 2) with mean $\mathrm{pH}$ ranging from 4.7 to 6.5 and acid neutralising capacity (ANC) from -32 to $168 \mu$ eq $\mathrm{l}^{-1}$. These variations are driven by spatial gradients in deposition, mediated by a

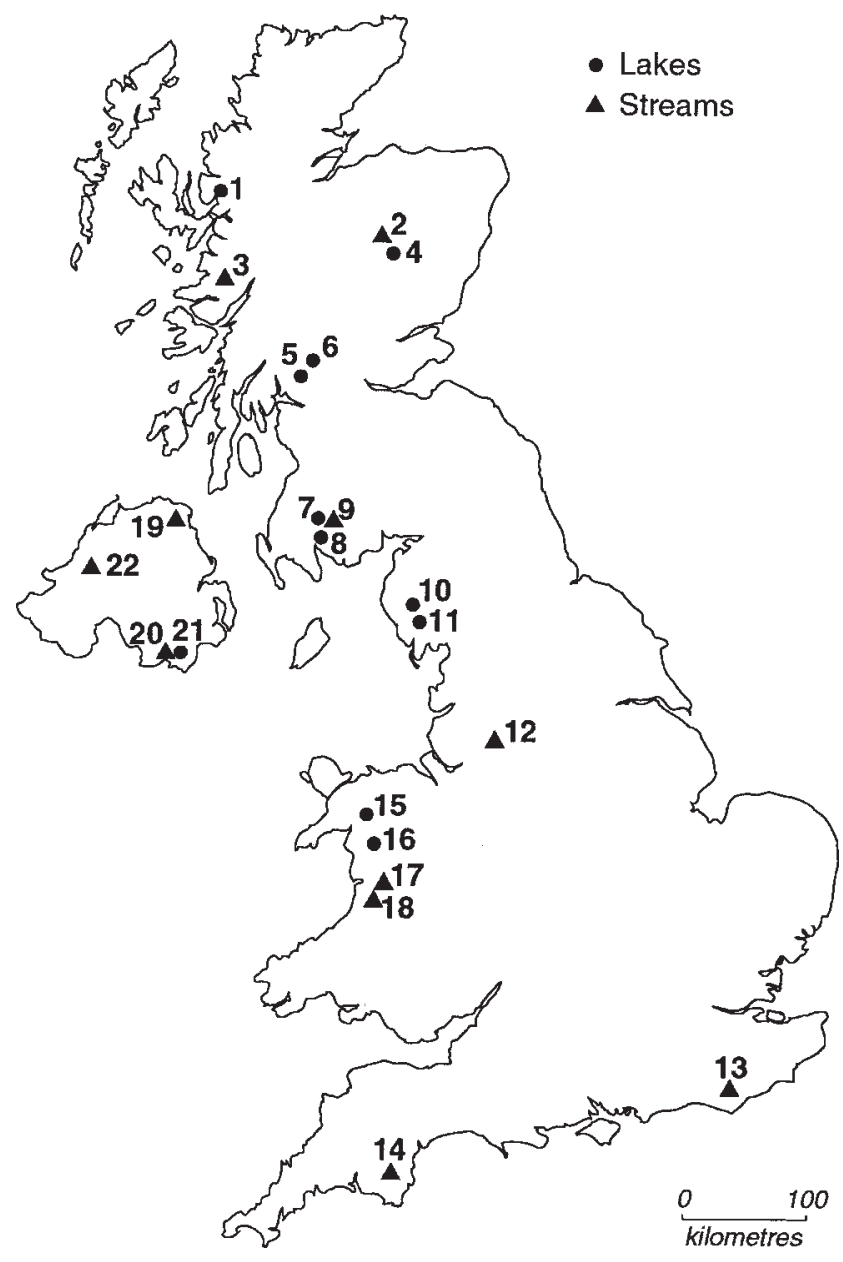

Fig. 1. Location of sites in the UK Acid Waters Monitoring Network. Site numbers correspond to list given in Table 1 
Table 1. Location and catchment characteristics of study sites

\begin{tabular}{|c|c|c|c|c|c|c|c|c|c|}
\hline Site & $\begin{array}{l}\text { UK Grid } \\
\text { Reference }\end{array}$ & Type & $\begin{array}{l}\text { Min. } \\
\text { Altitude } \\
m\end{array}$ & $\begin{array}{l}\text { Max. } \\
\text { Altitiude } \\
m\end{array}$ & $\begin{array}{l}\text { Lake } \\
\text { Area } \\
\text { ha }\end{array}$ & $\begin{array}{l}\text { Catchment } \\
\text { Area } \\
\text { ha }\end{array}$ & Geology & Soils & $\begin{array}{l}\text { Forest } \\
\text { area }\end{array}$ \\
\hline 1. Loch Coire nan Arr & NG 808422 & Lake & 125 & 896 & 12 & 909 & Sandstone & $\begin{array}{l}\text { Podzol, } \\
\text { gley, peat }\end{array}$ & - \\
\hline 2. Allt a'Mharcaidh & NH 881045 & Stream & 325 & 1111 & - & 998 & Granite & Podzol, peat & - \\
\hline 3. Allt na Coire nan Con & NM 793688 & Stream & 10 & 756 & - & 790 & $\begin{array}{l}\text { Schist, } \\
\text { gneiss }\end{array}$ & Peaty gley & $48 \%$ \\
\hline 4. Lochnagar & NO 252859 & Lake & 785 & 1155 & 10 & 101 & Granite & Alpine podzol & - \\
\hline 5. Loch Chon & NN 421051 & Lake & 100 & 600 & 100 & 1670 & Schist, grits & Podzol, gley & $56 \%$ \\
\hline 6. Loch Tinker & NN 445068 & Lake & 420 & 700 & 11 & 121 & Schist, grits & Peat & - \\
\hline 7. Round Loch of Glenhead & NX 450804 & Lake & 295 & 531 & 13 & 108 & Granite & $\begin{array}{l}\text { Peat, peaty } \\
\text { podzol }\end{array}$ & - \\
\hline 8. Loch Grannoch & NX 542700 & Lake & 210 & 601 & 114 & 1401 & Granite & $\begin{array}{l}\text { Gley, podzol, } \\
\text { peat }\end{array}$ & $70 \%$ \\
\hline 9. Dargall Lane & NX 449786 & Stream & 225 & 716 & - & 210 & $\begin{array}{l}\text { Shale, } \\
\text { greywackes }\end{array}$ & Peaty podzol & - \\
\hline 10. Scoat Tarn & NY 159104 & Lake & 602 & 841 & 5 & 100 & Volcanics & Peaty ranker & - \\
\hline 11. Burnmoor Tarn & NY 184044 & Lake & 252 & 602 & 24 & $\begin{array}{l}240 \\
\text { granite }\end{array}$ & $\begin{array}{l}\text { Volcanics, } \\
\text { peat }\end{array}$ & Ranker, podzol, & , - \\
\hline 12. River Etherow & SK 116996 & Stream & 280 & 633 & - & 1300 & Millstone grit & Peat & - \\
\hline 13. Old Lodge & TQ 456294 & Stream & 94 & 198 & - & 240 & Sandstone & $\begin{array}{l}\text { Brown podzol, } \\
\text { gley }\end{array}$ & - \\
\hline 14. Narrator Brook & SX 568692 & Stream & 225 & 456 & - & 253 & Granite & Podzols & - \\
\hline 15. Llyn Llagi & SH 649483 & Lake & 380 & 678 & 6 & 163 & $\begin{array}{l}\text { Slate, shale, } \\
\text { dolerite }\end{array}$ & $\begin{array}{l}\text { Peaty podzol, } \\
\text { peat }\end{array}$ & - \\
\hline 16. Llyn Cwm Mynach & SH 678238 & Lake & 285 & 680 & 6 & 159 & $\begin{array}{l}\text { Cambrian } \\
\text { sedimentary }\end{array}$ & Rankers, peat 5 & $55 \%$ \\
\hline 17. Afon Hafren & SN 844876 & Stream & 355 & 690 & - & 358 & Shale, gritstone & $\begin{array}{l}\text { Peaty podzol, } \\
\text { peat }\end{array}$ & $50 \%$ \\
\hline 18. Afon Gwy & SN 842854 & Stream & 440 & 730 & - & 389 & Shale, gritstone & $\begin{array}{l}\text { Peaty podzol, } \\
\text { peat }\end{array}$ & - \\
\hline 19. Beaghs Burn & D 173297 & Stream & 150 & 397 & - & 303 & Schist & Peat & - \\
\hline 20. Bencrom River & J 304250 & Stream & 140 & 700 & - & 216 & Granite & Peat & - \\
\hline 21. Blue Lough & J 327252 & Lake & 340 & 703 & 2 & 50 & Granite & Peat & - \\
\hline 22. Coneyglen Burn & H 641884 & Stream & 230 & 562 & - & 1311 & Schist & Peat & - \\
\hline
\end{tabular}

number of catchment-specific factors. In the UK, sources of $\mathrm{S}$ and $\mathrm{N}$ emissions are mainly concentrated in more populated and industrialised southern and eastern areas and are, therefore, remote from many of the most acid-sensitive regions. AWMN sites closest to these source areas, notably the River Etherow and Old Lodge, generally have the highest levels of $\mathrm{SO}_{4}$ and are strongly acidic, whereas the most remote sites, in northern Scotland and western Northern Ireland, are minimally impacted by anthropogenic deposition. This spatial gradient has also been evident in recent patterns of deposition reductions with large decreases in S deposition observed between 1986 and 1997 in areas near to emissions sources, but little evidence of change over the same period in the more remote regions where many AWMN sites are located (Fowler and Smith, 2000) (Fig. 2).

A key catchment factor influencing surface water acidity is geological buffering. Although all sites are in acidsensitive regions, calcium (Ca) concentrations, which provide an indication of weathering rates, vary widely between sites. In areas of more complex geology, closely located sites (e.g. Burnmoor and Scoat Tarns in the English Lake District) may consequently differ substantially in acidity despite similar deposition levels. Concentrations of sea-salts, such as $\mathrm{Cl}$, are generally higher close to western coasts, while nitrate $\left(\mathrm{NO}_{3}\right)$ appears to be strongly influenced 
Table 2. Long-term mean chemistry of study sites

\begin{tabular}{lllllll}
\hline Site & $\begin{array}{l}\text { ANC } \\
\left(\mu e q l^{-1}\right)\end{array}$ & $p H$ & $\begin{array}{l}x S O 4 \\
\left(\mu e q l^{-1}\right)\end{array}$ & $\begin{array}{l}\text { NO3 } \\
\left(\mu e q l^{-1}\right)\end{array}$ & $\begin{array}{l}C l \\
\left(\mu e q l^{-1}\right)\end{array}$ & $\begin{array}{l}\text { Ca } \\
\left(\mu e q l^{-1}\right)\end{array}$ \\
\hline 1. Loch Coire nan Arr & 42 & 6.39 & 14 & 3 & 256 & 43 \\
2. Allt a'Mharcaidh & 46 & 6.45 & 33 & 1 & 110 & 42 \\
3. Allt na Coire nan Con & 35 & 5.85 & 30 & 4 & 296 & 58 \\
4. Lochnagar & 3 & 5.33 & 48 & 16 & 89 & 29 \\
5. Loch Chon & 23 & 5.6 & 49 & 12 & 223 & 78 \\
6. Loch Tinker & 54 & 6.13 & 39 & 3 & 263 & 85 \\
7. Round Loch of Glenhead & -2 & 4.9 & 47 & 7 & 195 & 33 \\
8. Loch Grannoch & -27 & 4.61 & 72 & 17 & 257 & 48 \\
9. Dargall Lane & 9 & 5.52 & 60 & 11 & 186 & 50 \\
10. Scoat Tarn & -14 & 4.99 & 42 & 21 & 186 & 33 \\
11. Burnmoor Tarn & 49 & 6.48 & 59 & 5 & 210 & 90 \\
12. River Etherow & 31 & 5.48 & 240 & 49 & 310 & 172 \\
13. Old Lodge & -17 & 4.59 & 193 & 7 & 571 & 152 \\
14. Narrator Brook & 18 & 5.77 & 45 & 6 & 274 & 35 \\
15. Llyn Llagi & 12 & 5.34 & 41 & 10 & 194 & 53 \\
16. Llyn Cwm Mynach & 9 & 5.37 & 54 & 10 & 304 & 70 \\
17. Afon Hafren & 2 & 5.37 & 60 & 21 & 209 & 45 \\
18. Afon Gwy & 14 & 5.55 & 48 & 11 & 159 & 40 \\
19. Beaghs Burn & 92 & 5.76 & 38 & 4 & 367 & 103 \\
20. Bencrom River & 3 & 5.19 & 67 & 29 & 256 & 53 \\
21. Blue Lough & -32 & 4.69 & 66 & 29 & 276 & 40 \\
22. Coneyglen Burn & 168 & 6.51 & 30 & 3 & 256 & 149 \\
& & & & & & \\
\hline
\end{tabular}

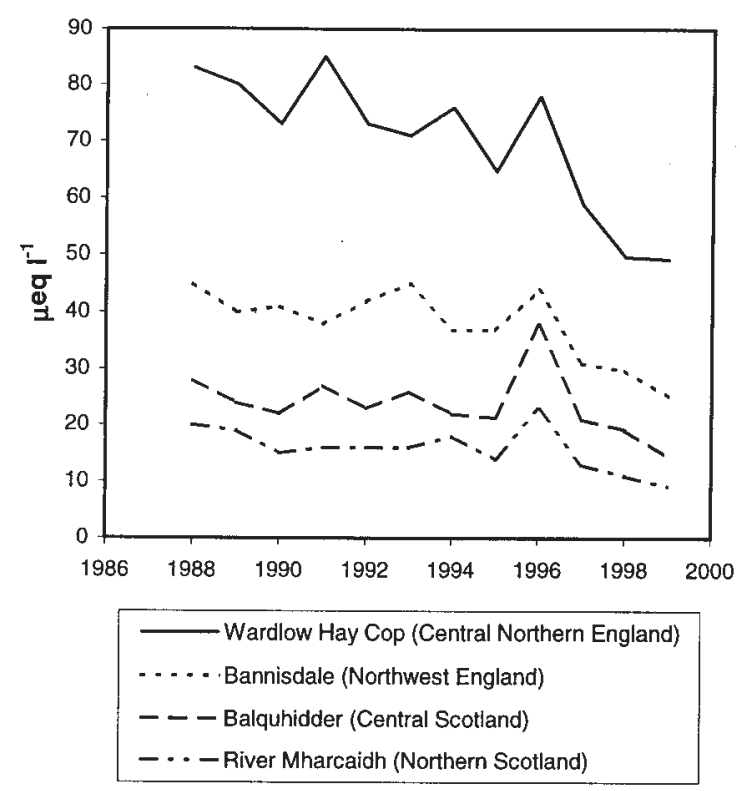

Fig. 2. Volume-weighted annual mean non-marine $\mathrm{SO}_{4}$ concentrations in rainfall, 1988-1999, at a transect of sites from Central Northern England (high deposition) to Northern Scotland (low deposition). Data from the UK Acid Deposition Monitoring Network (Campbell et al., 1998). Concentrations peaks in 1996 reflect low rainfall in that year. by catchment morphology, with the highest concentrations observed at steep, high-elevation sites such as Lochnagar and Scoat Tarn, where soils are thin and biologic activity is low (Kernan and Allott, 1999). Forested sites are consistently more acidic than moorland sites in the same regions (Monteith and Evans, 2000).

\section{Methods}

Temporal trends in water chemistry have been assessed for all 22 sites using the non-parametric Seasonal Kendall Test (SKT) (Hirsch et al., 1982; Hirsch and Slack, 1984), and slopes estimated using the method of Sen (1968). This methodology was applied to all monitoring data within the RECOVER:2010 project and is described in detail by Evans et al. (2001b). A significance threshold of $\mathrm{p}<0.05$ was applied to all trend analyses. Trends were assessed for $\mathrm{H}$, alkalinity, $\mathrm{ANC}, \mathrm{SO}_{4}$, non-marine sulphate $\left(\mathrm{xSO}_{4}\right), \mathrm{NO}_{3}, \mathrm{Cl}$, $\mathrm{Na}, \mathrm{Ca}$, Magnesium $(\mathrm{Mg}$ ), labile (free and inorganically complexed) $\mathrm{Al}$, non-labile (organically complexed) $\mathrm{Al}$ and dissolved organic carbon (DOC). For this study, ANC was calculated according to the equation: 


$$
\mathrm{ANC}=\text { Alkalinity }+(\mathrm{F} \times \mathrm{DOC})-(3 \times \text { labile } \mathrm{Al})
$$

where ANC and alkalinity (measured by dual end point titration) are expressed in $\mu$ eq $\mathrm{l}^{-1}$, and DOC and labile $\mathrm{Al}$ in $\mu \mathrm{mol} \mathrm{l^{-1 }}$. F represents the charge density of DOC at the equivalence point, estimated as 0.054 for samples with $\mathrm{pH}$ $<5.5$, and 0.060 for samples with $\mathrm{pH}>5.5$ (Harriman and Taylor, 1999). This equation also assumes that all inorganic $\mathrm{Al}$ is present as $\mathrm{Al}^{3+}$ at the equivalence point (Neal et al., 1999) and that all organic Al is undissociated. Although ANC is more commonly calculated as the difference between the sum of base cations and the sum of acid anions (Reuss et al., 1986), the random analytical errors associated with this estimate have been shown to be relatively large, especially at sites with high sea-salt concentrations (Evans et al., 2001c). This is a particular problem when attempting to detect long-term trends, which may only be in the order of $1 \mu \mathrm{eq} \mathrm{l}^{-1} \mathrm{yr}^{-1}$ and Eqn. (1) was, therefore, used in preference.

Given the large number of sites and chemical variables under consideration, general patterns in time series were examined by transforming raw data to a more directly comparable form. Concentration data were standardised by subtracting the mean of the full sample set, and dividing by the standard deviation, such that all standardised time series have a mean of zero and a standard deviation of one. At each sampling time, a median of standardised concentrations for all sites was taken and used to generate a dimensionless 'regional time series' in which a positive value at any given time demonstrates generally above-average concentrations and a negative value below-average concentrations (Fig. 3 ). An indication of the variation about these median values was obtained by determining the second-lowest and secondhighest standardised concentrations at each sampling time (for 11 lake or stream sites, this represents the $10^{\text {th }}$ and $90^{\text {th }}$ percentile). This approach is intended to reveal underlying patterns of regional response and has the advantage that anomalous extreme values, which may obscure trends at individual sites, tend to be excluded. Generally, the narrower the band delimiting the second-highest or second-lowest value, the stronger the temporal coherence across the region. The method has previously been applied to a subset of six high-elevation moorland AWMN lakes by Evans and Monteith (2001) and is extended here to include all 22 sites in the network. Lakes and streams are, however, considered separately due to differences in sampling frequency and potentially also in chemical response. The differing spatial distribution of lakes and streams within the network also has the potential to influence results.

Variables included in the standardised analysis were ANC, $\mathrm{H}, \mathrm{SO}_{4}, \mathrm{xSO}_{4}, \mathrm{NO}_{3}, \mathrm{Cl}, \mathrm{Ca}, \mathrm{DOC}$, labile and non-labile $\mathrm{Al}$.
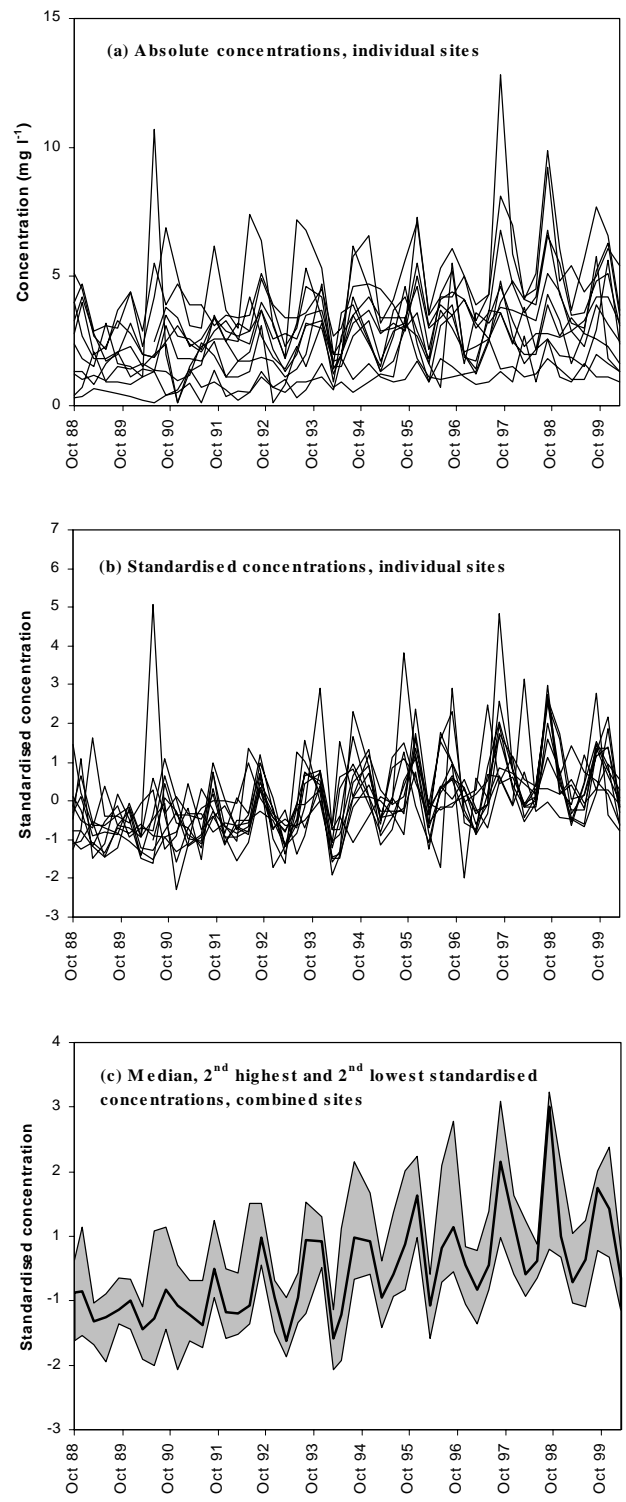

Fig. 3. Example of the use of median standardised concentrations to illustrate patterns of temporal change at multiple monitoring sites

Data series with more than $50 \%$ of values below detection limits, however, (labile Al at Loch Coire nan Arr, Allt a'Mharcaidh, Loch Tinker, Burnmoor Tarn, Coneyglen Burn; $\mathrm{NO}_{3}$ at Allt a'Mharcaidh, Coneyglen Burn) were not used to generate plots. Time series of median standardised concentrations were analysed for trends using the same methods applied to raw concentration data and the stream and lake datasets were further subdivided into those with moorland and forest catchments. The size of the dimensionless slopes obtained is not particularly meaningful, but their direction and significance provide a valuable indicator of changes occurring within the network as a whole. 


\section{Results}

\section{TRENDS AT INDIVIDUAL SITES}

Significant $(\mathrm{p}<0.05)$ Seasonal Kendall trends for individual sites (Table 3 ) show a fair degree of consistency within the network. Where observed, trends are generally indicative of recovery from acidification with ANC increasing significantly at ten sites, alkalinity at four, and $\mathrm{H}$ and labile Al both decreasing at seven. Only at the forested Loch Grannoch is there any evidence of continued acidification with $\mathrm{H}$ having risen significantly over the study period. Considering all trend slopes regardless of significance (Fig. 4) suggests a more general reduction in acidity with ANC having risen and $\mathrm{H}$ and labile $\mathrm{Al}$ fallen at the majority of sites in the network. Overall patterns of change in alkalinity are less clear, with a number of sites showing small nonsignificant decreases. The large non-significant decrease at one site, Coneyglen Burn, is actually small relative to the high mean alkalinity of this site $\left(152 \mu \mathrm{eq}^{\mathrm{l}^{-1}}\right)$ and does not indicate major acidification. (a) $\mathrm{pH}$

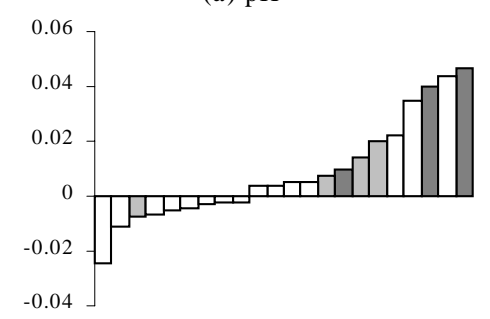

(d) Sulphate

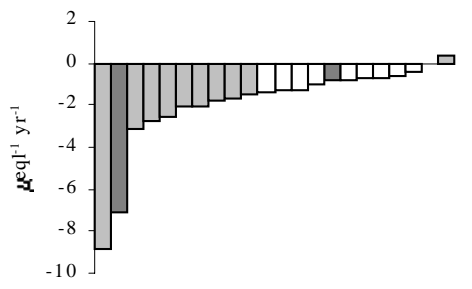

(g) Nitrate

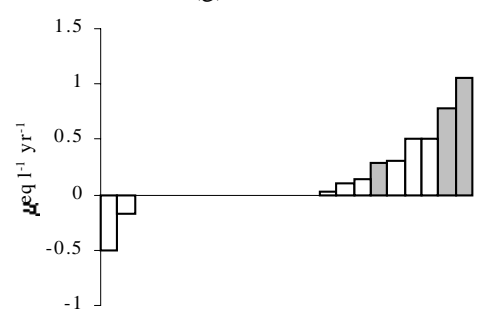

(j) Dissolved organic carbon

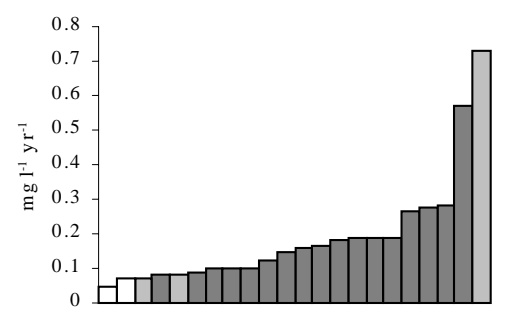

(b) ANC

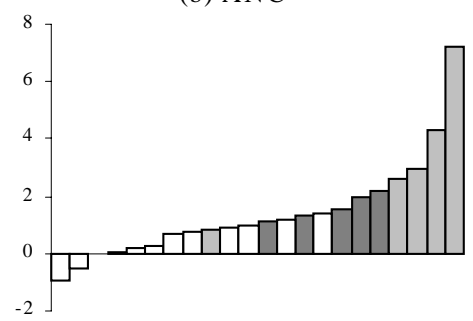

(e) Non-marine sulphate

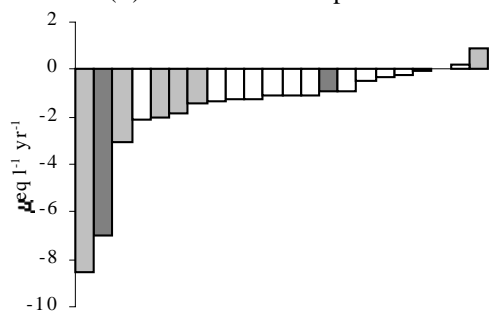

(h) Chloride

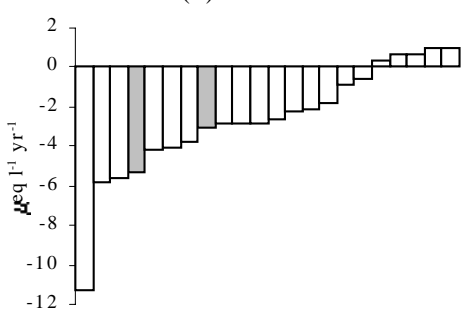

(k) Organic aluminium

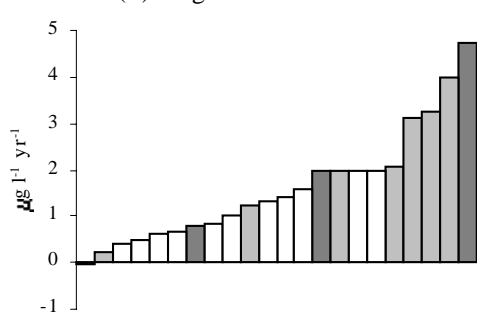

(c) Alkalinity

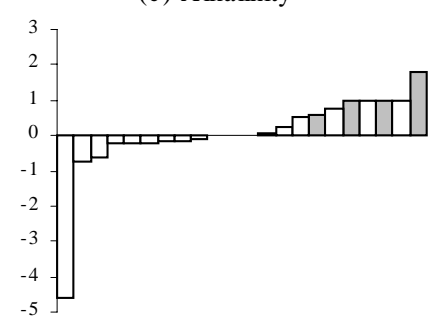

(f) Calcium

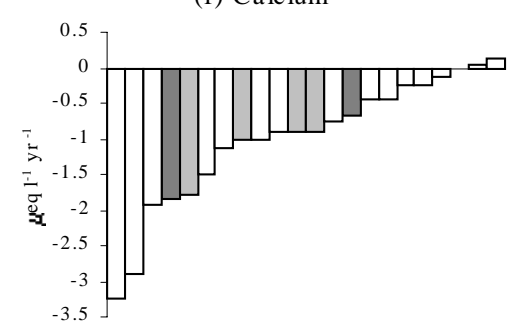

(i) Sodium

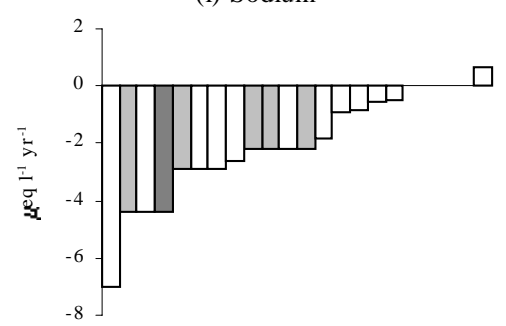

(1) Inorganic a luminium

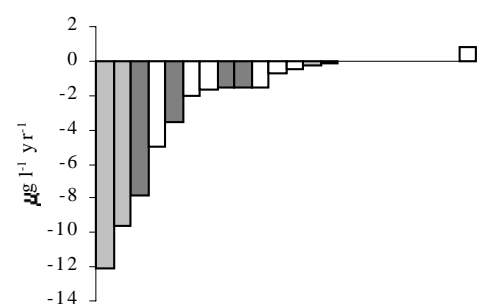

$\square \mathrm{p}<0.01 \quad \square \mathrm{p}<0.05 \quad \square \mathrm{p}>0.05$

Fig. 4. Estimated trend slopes for all AWMN sites, ordered by slope estimate 


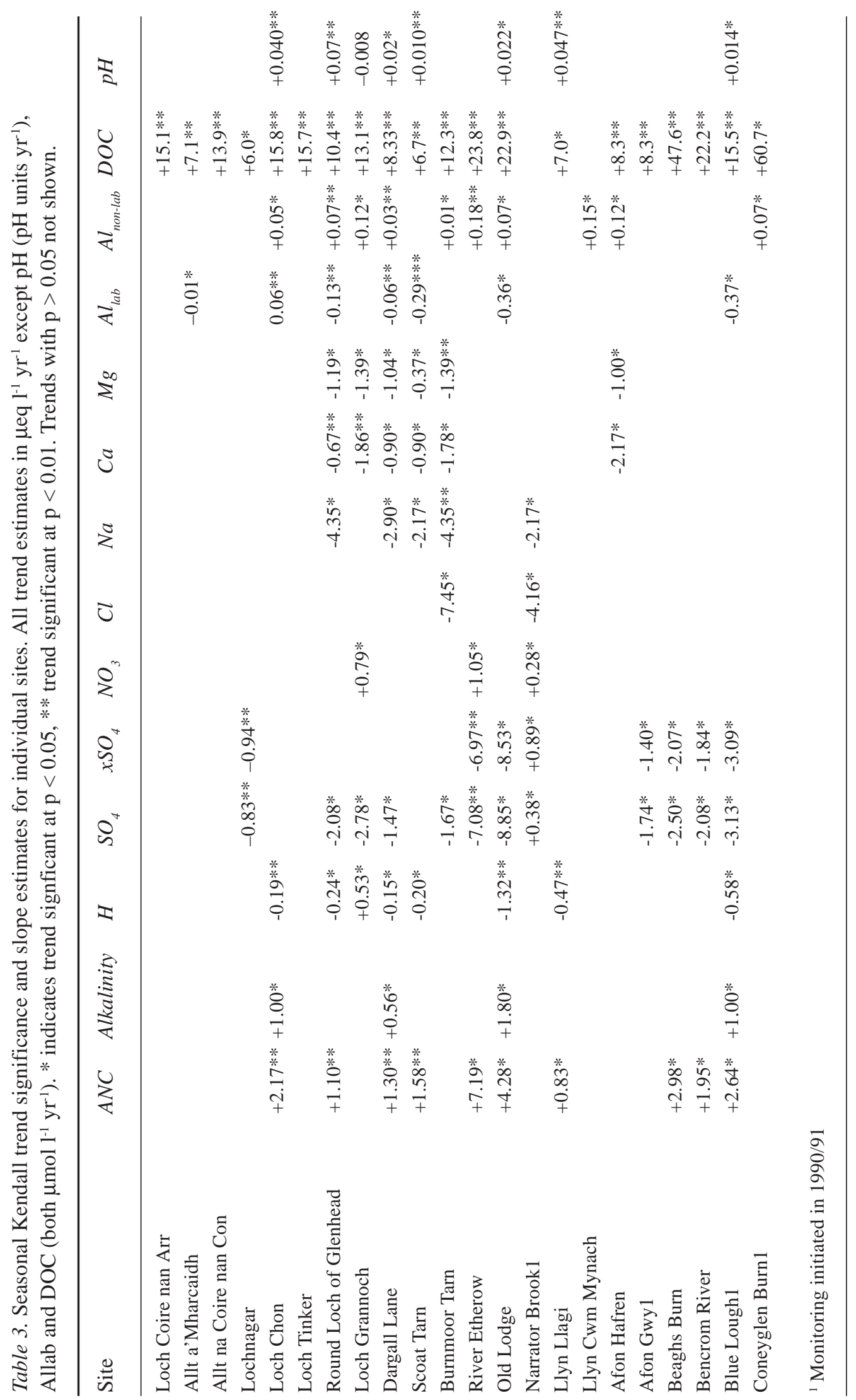


Given the large decrease in S emissions during the 1980s and 1990s, it might be assumed that observed reductions in acidity have been driven by decreases in surface water $\mathrm{SO}_{4}$ concentrations. To some extent this is supported by the trend analysis with significant falls in $\mathrm{SO}_{4}$ recorded at 12 sites and negative slopes at all but two sites (Fig. 4e). Decreases in $\mathrm{xSO}_{4}$, however, are only significant at eight sites and of the 10 sites with rising ANC, only five have significant $\mathrm{xSO}_{4}$ trends. It appears, therefore, that part of the $\mathrm{SO}_{4}$ reduction observed since 1988 has been in the marine component and also that reductions in acidity over the last 12 years are not simply a function of falling anthropogenic $\mathrm{S}$ inputs. For the other major acidifying anion, $\mathrm{NO}_{3}$, there is little evidence of widespread change over the monitoring period. Three sites exhibit significant rising trends but at the majority of sites, trend slopes are close to zero. Calcium concentrations have fallen at six sites, primarily in the Lake District and Galloway, and a similar pattern is observed for $\mathrm{Mg}$. The main sea-salt ions, $\mathrm{Na}$ and $\mathrm{Cl}$, both show a general pattern of reducing concentrations since 1988, but relatively few trends are significant.

The most widespread change observed in the AWMN over the last 12 years has been a strong increase in DOC. This has risen at every site in the network and trends are significant at 20 sites (three more than for the 1988-1998 period), most at $\mathrm{p}<0.01$. Non-labile $\mathrm{Al}$ has also risen significantly at 10 sites and non-significantly at a further 11 sites. These increases in the organic component of $\mathrm{Al}$ appear closely correlated to those in DOC and are consistent with concentrations being determined by the availability of the organic matter for complexation (Driscoll et al., 1984). As a result of the opposing changes in the labile and non-labile $\mathrm{Al}$ fractions, total soluble $\mathrm{Al}$ has remained relatively unchanged at most sites.

\section{TRENDS AT COMBINED LAKE SITES}

Time series of standardised concentrations for lakes (Fig. 5) suggest highly coherent temporal variations at different sites with, in most instances, a relatively narrow range between the second highest and second lowest values observed at each sampling time. Despite differences in deposition, climate, geology, soils and land-use between sites, therefore, it appears that the underlying factors controlling temporal change are to some extent uniform across the study region.

These plots, together with trend analyses of median standardised concentrations (Table 4), allow a number of general patterns at the 11 lakes to be identified. Despite strong seasonality, it is clear that ANC has risen significantly during the 12-year period and that $\mathrm{H}$ and labile $\mathrm{Al}$ concentrations have both fallen. These observations support the conclusion of individual site analyses that surface waters have tended to become less acidic since 1988. Long-term changes in $\mathrm{SO}_{4}$ and $\mathrm{xSO}_{4}$ are also strongly consistent among sites but $\mathrm{xSO}_{4}$ in particular does not exhibit a linear decrease. As noted earlier, high total $\mathrm{SO}_{4}$ concentrations in the early part of the record were in part due to high marine $\mathrm{SO}_{4}$ deposition at this time. This is well illustrated by time series for $\mathrm{Cl}$ which, although fairly constant since 1993 (as a result of which SKT trends are not significant), was clearly much higher from 1989 to 1992. In more recent years, falling standardised concentrations of both $\mathrm{SO}_{4}$ and $\mathrm{xSO}_{4}$ suggest a widespread response to reductions in pollutant deposition at most or all lake sites, with recent concentrations lower than any that have been observed previously at these sites. These results are consistent with observed precipitation chemistry (Fig. 2) which indicates widespread decreases in recent years. Although rates of $\mathrm{xSO}_{4}$ decline have been greatest since 1997, large $\mathrm{xSO}_{4}$ peaks at individual sites in winter 1995/96 have been attributed to flushing following a widespread drought in the preceding summer (Harriman et al., 2001). It is probable, therefore, that the underlying $\mathrm{xSO}_{4}$ trend has been downward since around 1994.

Although there does not seem to be any UK-wide longterm trend in $\mathrm{NO}_{3}$, inter-annual variations are consistent between lakes with the large climate-driven spring 1996 peak observed at all locations. Median standardised Ca has

Table 4. Direction and significance of trends in median standardised concentrations for grouped lakes and streams. Trends are based on the median of standardised concentrations for each site. Single arrows indicate trend significance at 0.05 level, double arrows indicate trend significant at 0.01 level.

\begin{tabular}{|l|l|c|c|c|c|c|c|c|c|c|c|c|}
\hline & $\mathrm{N}$ & $\mathrm{SO}_{4}$ & $\mathrm{xSO}_{4}$ & $\mathrm{ANC}$ & $\mathrm{H}$ & $\mathrm{Al}_{\text {labile }}$ & $\mathrm{Ca}$ & $\mathrm{NO}_{3}$ & $\mathrm{Cl}$ & $\mathrm{Alk}$ & $\mathrm{DOC}$ & $\mathrm{Al}_{\text {non-labile }}$ \\
\hline All lakes & 10 & $\downarrow$ & - & $\uparrow \uparrow$ & $\downarrow \downarrow$ & $\downarrow \downarrow$ & $\downarrow$ & - & - & - & $\uparrow \uparrow$ & $\uparrow \uparrow$ \\
Moorland lakes & 7 & $\downarrow$ & - & $\uparrow \uparrow$ & $\downarrow$ & $\downarrow \downarrow$ & $\downarrow$ & - & - & - & $\uparrow \uparrow$ & $\uparrow \uparrow$ \\
Forested lakes & 3 & - & - & $\uparrow$ & - & $\downarrow$ & $\downarrow$ & $\uparrow$ & - & - & $\uparrow \uparrow$ & $\uparrow$ \\
\hline All streams & 11 & $\downarrow$ & $\downarrow$ & $\uparrow$ & - & - & - & - & - & - & $\uparrow \uparrow$ & $\uparrow$ \\
Moorland streams & 9 & $\downarrow$ & $\downarrow$ & $\uparrow$ & - & $\downarrow \downarrow$ & - & - & - & - & $\uparrow \uparrow$ & $\uparrow$ \\
Forested streams & 2 & - & - & - & - & - & $\downarrow$ & - & - & - & $\uparrow \uparrow$ & $\uparrow$ \\
\hline
\end{tabular}



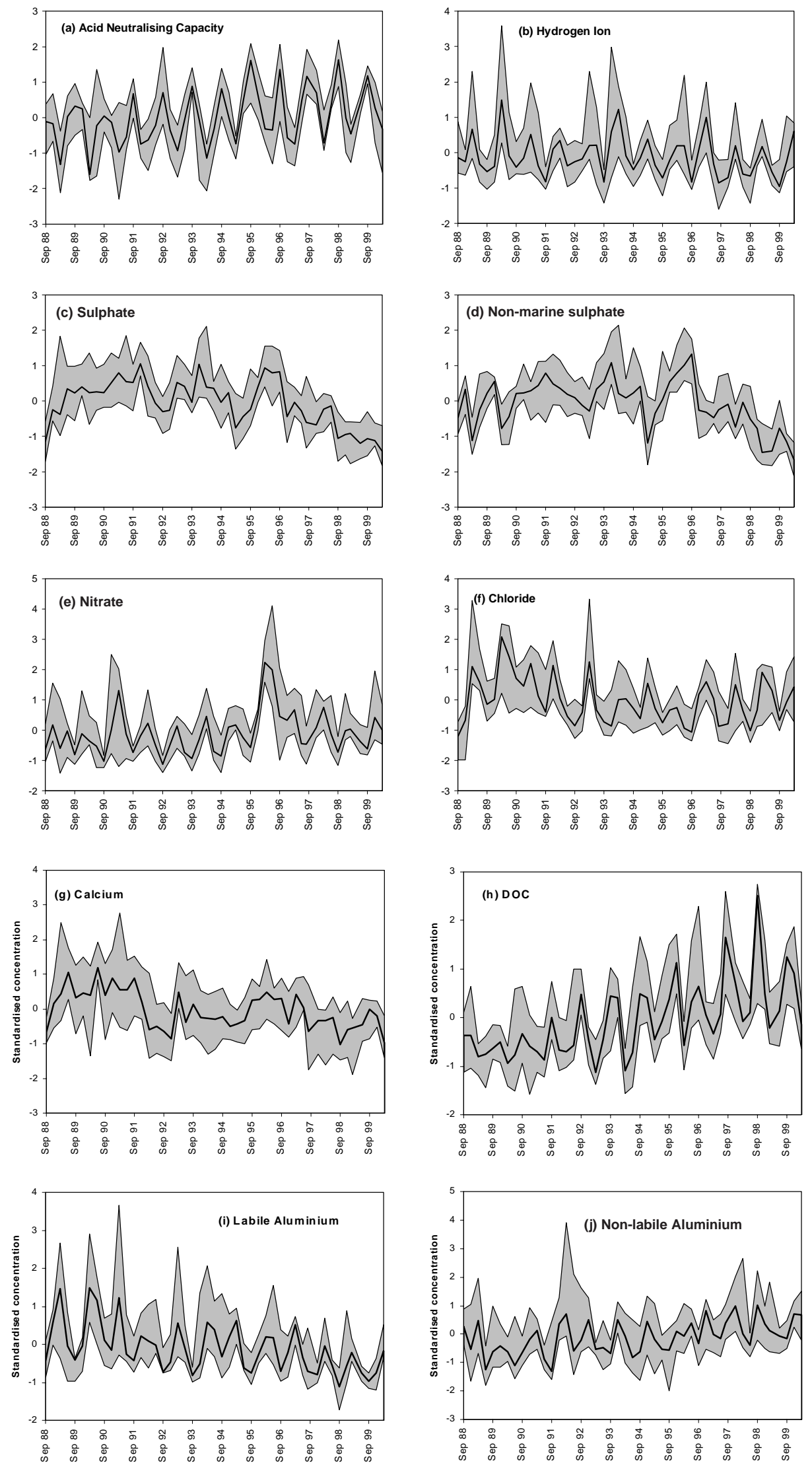

Fig. 5. Standardised concentration time series, lakes. Bold solid line shows the median standardised concentration for the eleven lakes, and shaded areas the range between $2^{\text {nd }}$ highest and $2^{\text {nd }}$ lowest standardised concentrations, for each sampling time 
fallen over the monitoring period and is closely correlated to $\mathrm{SO}_{4}$. High concentrations in 1989-1991 are thought to result from the peak in sea-salt deposition with Ca displaced (along with $\mathrm{H}$ and labile $\mathrm{Al}$ ) from soil exchange sites by marine $\mathrm{Na}$ and $\mathrm{Mg}$ (Evans et al., 2001a). Subsequently, the decrease in $\mathrm{Ca}$ leaching by acid deposition has led to a general fall in $\mathrm{Ca}$ concentrations. Base cation decreases effectively damp ANC response to changes in $\mathrm{SO}_{4}$ and have been widely observed elsewhere in Europe and North America (eg Stoddard et al., 1999; Evans et al., 2001a). Since reductions in non-marine base cations have generally been smaller than those in $\mathrm{xSO}_{4}$, however, ANC has increased.

In accordance with the strong individual site trends, highly significant rising trends are observed for both DOC and nonlabile Al. Increases have been approximately linear over the 12-year period (Fig. 5) and rising trends are apparent in both seasonal maxima and minima. The mechanisms for, and the significance of, these trends are discussed below.

\section{TRENDS AT COMBINED STREAM SITES}

Standardised concentration time series for streams (Fig. 6) are noisier than those for lakes, due partly to the higher sampling frequency but also to the greater impact of episodes in streams. Without the damping effect of lake storage, the range of solute concentrations observed is generally higher and underlying trends in some cases more difficult to detect as a result. In addition, band widths tend to be greater than those for lake sites suggesting weaker temporal coherence. This is perhaps not surprising given the wider geographical spread of streams relative to lakes (Fig. 1). A number of clear temporal patterns remains evident, however, and in most cases corresponds to those observed for lakes. Sulphate concentrations were clearly highest during the early $1990 \mathrm{~s}$ and have declined since, with a similar but perhaps slightly delayed reduction observed for $\mathrm{xSO}_{4}$. The $\mathrm{S}$ flush following the 1995 drought is highly pronounced in most streams. Although an upward trend is observed in median standardised ANC (Table 4), it is weaker than that observed for lakes and trends for $\mathrm{H}$ and labile $\mathrm{Al}$ are not significant. This is due to the high degree of episodicity, particularly for $\mathrm{H}$, although episode maxima in $\mathrm{H}$ and labile $\mathrm{Al}$ have both perhaps declined over the monitoring period.

Nitrate variations largely correspond to those for lakes, with strong and spatially consistent inter-annual variations in spring peak values but no overall trend. Calcium variations also correspond well to observations at lakes, with high concentrations coinciding with the peak in sea-salt deposition around 1990 and a second peak concurrent with the 1995-96 $\mathrm{SO}_{4}$ flush. Although the downward trend is not significant ( $\mathrm{p}=0.067)$ over the full 12-year period, concentrations do appear to have fallen along with $\mathrm{SO}_{4}$ in recent years. DOC and non-labile $\mathrm{Al}$ concentrations again show strong, linear upward trends, although for DOC it appears that increases have been greater in seasonal/episode maxima than in minima.

Although short-term variability to some extent masks long-term trends at stream sites, the underlying patterns observed remain consistent with the lakes with recovery over the last 12 years. A direct comparison between median standardised concentrations for lakes and streams (Fig. 7) shows clear similarities between the two surface water types in terms of both long-term trends and inter-annual variations. This suggests: (i) that in-lake processes have not greatly influenced temporal patterns at lake sites; and (ii) that differences in the geographical distribution of lakes and streams within the AWMN have not led to major systematic differences in chemical trends between the two surface water types.

\section{EFFECTS OF FORESTRY ON RECOVERY FROM ACIDIFICATION}

Coniferous forestry planting in the UK has been shown to increase acidification of surface waters (e.g. Harriman and Morrison, 1982) through a combination of enhanced dry deposition of acidifying pollutants to the forest canopy (Mayer and Ullrich, 1977), base cation uptake by the growing trees (Miller, 1981) and decreased water yield causing a concentration of pollutants in runoff (Neal et al., 1986). At three sets of paired catchments in the AWMN, forested catchments have consistently higher concentrations of $\mathrm{xSO}_{4}$ and $\mathrm{NO}_{3}$ and are more acid than nearby moorland sites (Monteith and Evans, 2000). In addition to this apparent enhancement of present-day acidity, dynamic modelling studies suggest that forest growth may reduce, or even negate, recovery of surface waters in response to reducing acid deposition (Jenkins et al., 1997). This will occur where uptake by the forest and leaching by acid anions together exceed the supply of base cations from weathering, leading to continued depletion of soil base saturation. With many forest plantations in the UK at or near maturity, harvesting and replanting may intensify this problem.

To compare long-term trends, median standardised concentrations were calculated separately for forest and moorland lakes and streams. Time series for lakes (Fig. 8) and trends for each subset (Table 4) show strong similarities in temporal variation for a number of variables, most strikingly $\mathrm{xSO}_{4}$, suggesting that moorland and forest catchments have responded in a similar fashion to deposition changes (streams are not shown as short-term variability 

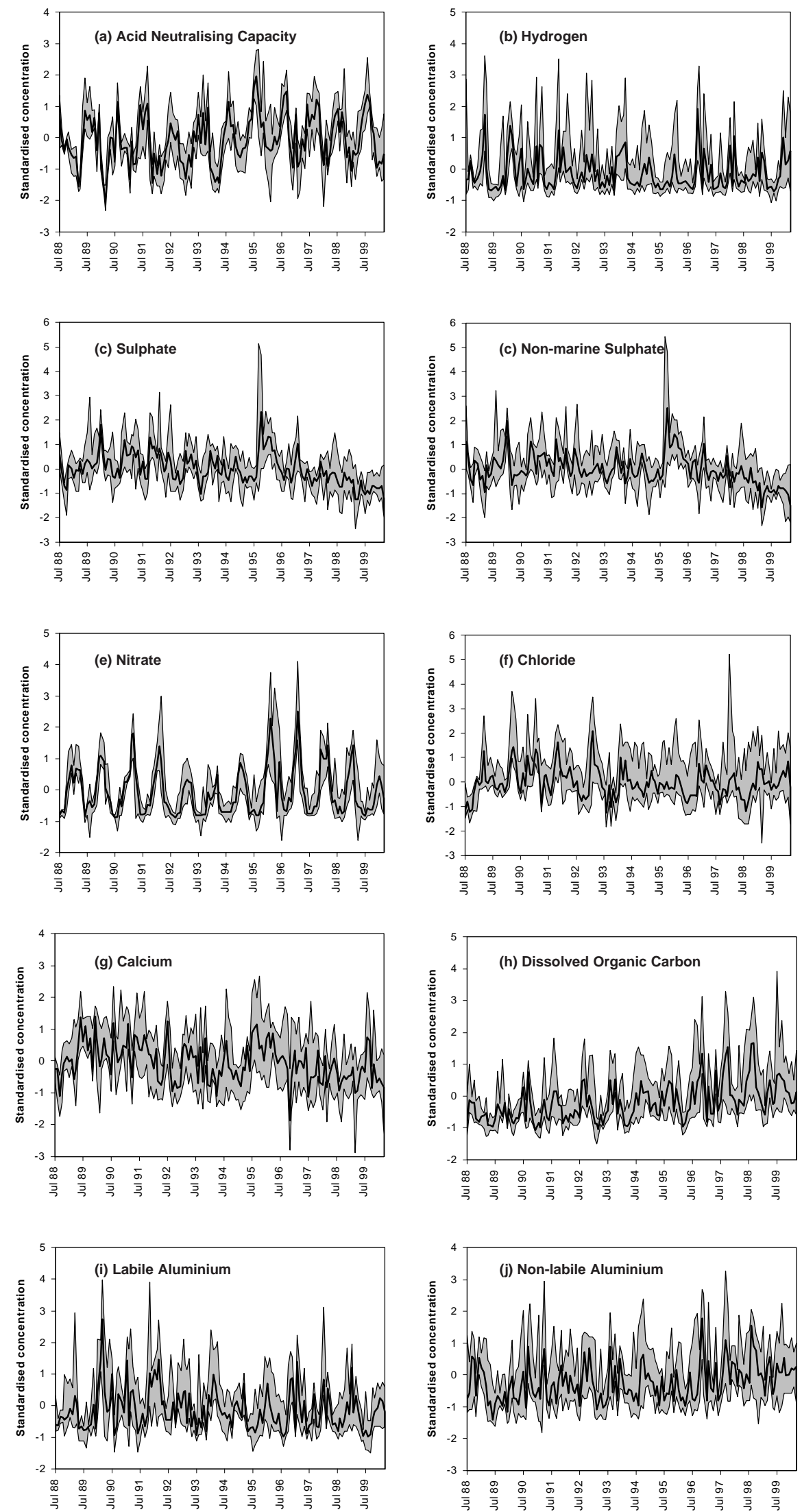

Fig. 6. Standardised concentration time series, streams. Bold solid line shows the median standardised concentration for the eleven streams, and shaded areas the range between $2^{\text {nd }}$ highest and $2^{\text {nd }}$ lowest standardised concentrations, for each sampling time. 

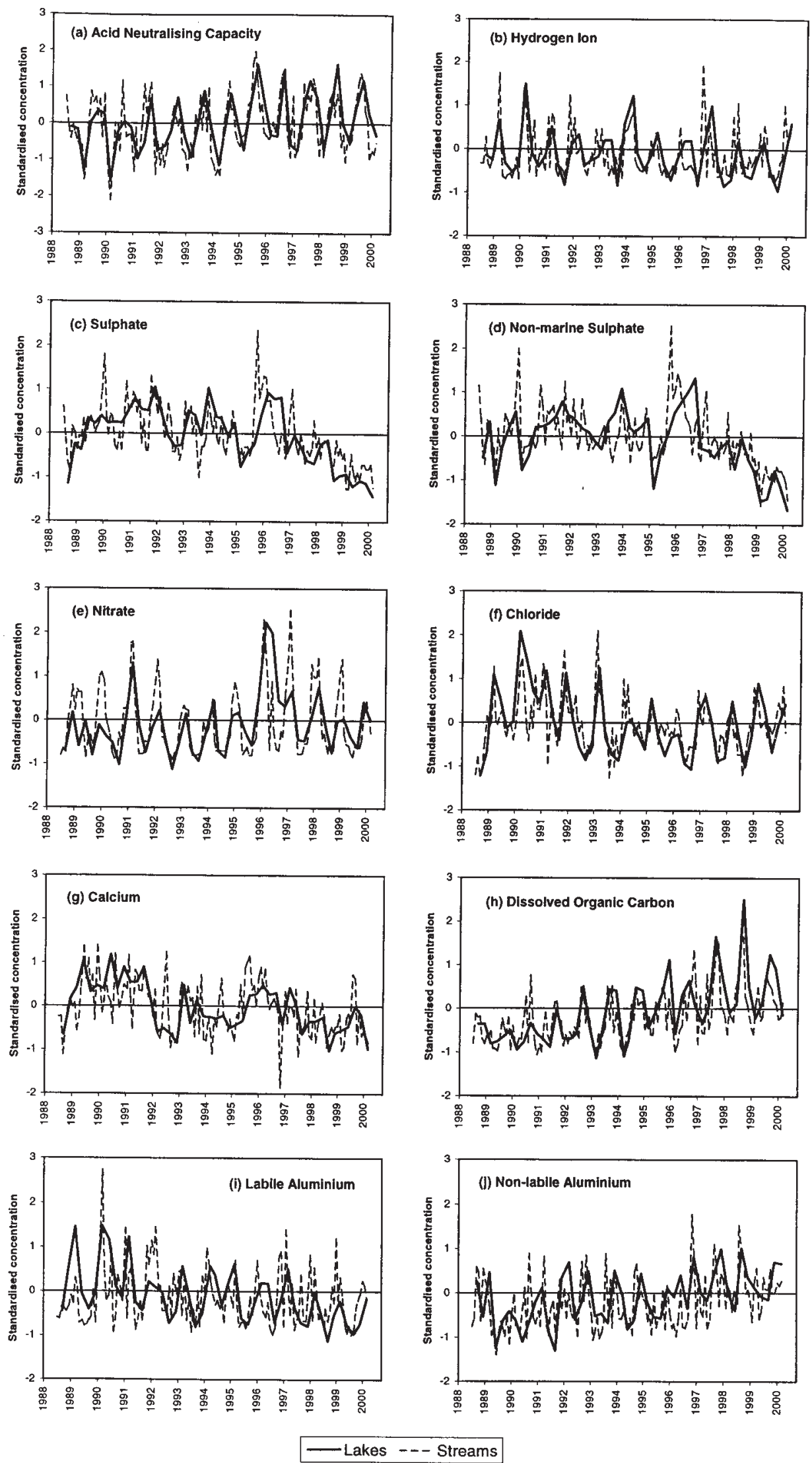

Fig. 7. Comparison of median standardised concentrations for lakes and streams 

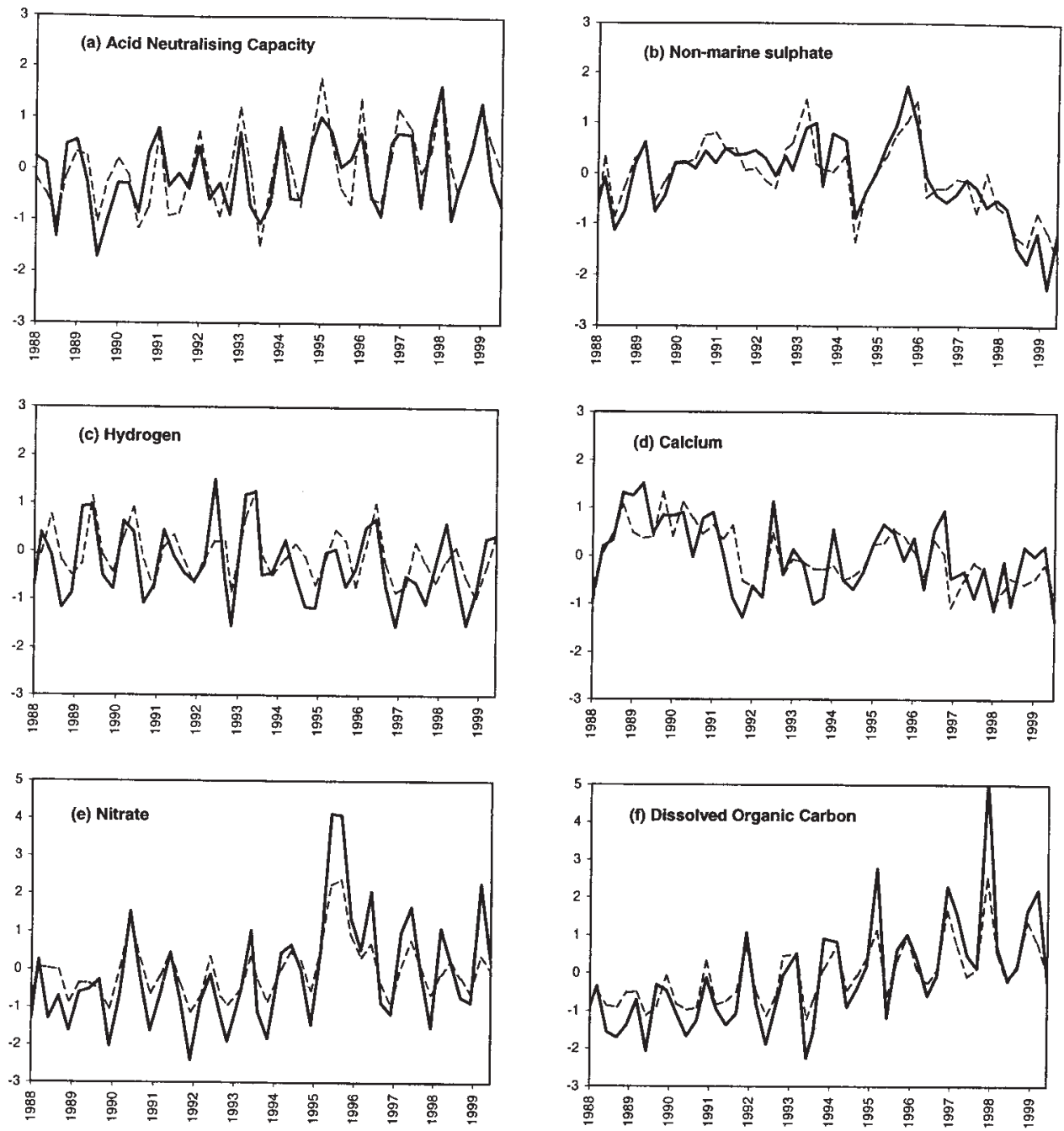

- Forest --- Moorland

Fig. 8. Comparison of median standardised concentrations for moorland and forested lakes

makes visual comparison difficult). It is difficult from this relatively short dataset to discern any long-term divergence in trends between moorland and forest systems, but in general trends in acidity-related variables appear weaker for forests than moorlands (Table 4). Additionally, these grouped data mask some heterogeneity between individual forested sites with Loch Chon exhibiting strong trends towards recovery in ANC, $\mathrm{H}$ and labile $\mathrm{Al}$ (Table 3), whilst other sites either show no trends in these variables or in the case of $\mathrm{H}$ at Loch Grannoch, evidence for continued acidification. At both Loch Grannoch and the Afon Hafren, downward trends in $\mathrm{Ca}$ exceed those for moorland sites in the same regions, possibly suggesting depletion of soil base cations by forest uptake.

Overall, therefore, given the small number of forest sites in the AWMN and their apparent heterogeneity, it is difficult to generalise regarding the impact of forests on recovery. It is likely that trends at forested sites will vary according to the supply of base cations from weathering; at sites where weathering supplies exceed uptake and leaching demands under reduced acid deposition, recovery will be observed (as at Loch Chon) whereas at sites where weathering is insufficient to meet this demand (perhaps at Loch Grannoch) recovery may not occur and in some cases acidification may continue.

\section{Discussion}

Any approach whereby large numbers of sites are grouped together to generate a single 'regional' temporal pattern 
necessarily involves some loss of information regarding changes at individual sites. In this study, the median standardised concentrations used to assess recovery undoubtedly mask considerable spatial heterogeneity among acid sensitive surface waters in the UK, with greater change expected, and observed, at acidified sites in high-deposition regions than at more remote, unimpacted sites. Catchmentspecific factors such as land-use, altitude, levels of sea-salt deposition and the presence of standing waters may also influence the behaviour of individual sites. Nevertheless, the analysis undertaken has revealed underlying patterns of temporal change that appear to have operated across much, or all, of the AWMN. These patterns should therefore be fairly representative of changes in acid-sensitive waters across the UK as a whole.

At a simple level, chemical changes during the 12 years of AWMN monitoring can be divided into two periods. From 1988 to 1993 there appears to have been little change in pollutant $\mathrm{SO}_{4}$ concentrations and, therefore, in the anthropogenic contribution to freshwater acidity. This was also a period of elevated storm intensity in the UK, however, leading to higher rainfall and at many sites, increased marine ion deposition. Combined effects of dilution and 'sea-salt effect' displacement of soil $\mathrm{H}$ and $\mathrm{Al}$ led to naturally elevated freshwater acidity during this time. During the second period, from 1994 onwards, marine ion deposition appears to have been lower and more stable whereas anthropogenic $\mathrm{S}$ inputs decreased. Consequently, apart from a droughtrelated flush in the winter of 1995/96, the trend in $\mathrm{XSO}_{4}$ has clearly been downward during this period. It appears coincidental that, in terms of acidity, these two phases of chemical change have combined to cause an approximately linear increase in ANC over the 12-year period, with accompanying decreases in $\mathrm{H}$, labile $\mathrm{Al}$ and also $\mathrm{Ca}$.

Nitrate, although subject to large climatically-driven interannual cycles, does not exhibit the widespread rising trends that might indicate decreasing retention of $\mathrm{N}$ deposition by soils and vegetation. This ongoing process of ' $\mathrm{N}$ saturation' has been widely predicted (e.g. Aber et al., 1989; Stoddard, 1994), but long-term data for the UK and for other European freshwaters (Wright et al., 2001) do not indicate that such changes are currently occurring. In contrast, concentrations of DOC have risen significantly and in an approximately linear fashion, at lakes and streams throughout the UK since 1988. Since DOC concentrations are affected by many factors, including soil acidity, temperature and moisture content (Kalbitz et al., 2000), it is difficult to isolate the cause of this increase. Previous studies (e.g. Krug and Frink, 1983; Tipping and Hurley, 1988) have suggested an inverse link between mineral acid inputs and the leaching of organic acidity (and hence DOC) to runoff. It is thus possible that increased DOC concentrations in the UK represent a response to reductions in soil and stream acidity over the last 12 years. The large increases in DOC observed at a number of relatively unimpacted sites in north-west Scotland and north-west Northern Ireland (Table 2), however, argue against an acidity control at all sites and suggest that climatic factors may also be important. It has recently been suggested that peat decomposition may be strongly regulated by an enzyme, phenol oxidase, which appears highly sensitive to climatic variation (Freeman et al., 2001). Changes in the decomposition of peat soils would directly impact DOC output.

While the controlling mechanisms remain uncertain, it is interesting to note that from Eqn. (1), increases in DOC have in effect constituted part of the observed increases in ANC. Converting DOC trends using the charge density estimates given earlier, organic acidity is estimated to have increased by between 3 and $44 \mu$ eq $1^{-1}$ at individual sites since 1988 (median of all sites $+9 \mu$ eq $\mathrm{l}^{-1}$ ). By comparison, $\mathrm{xSO}_{4}$ has changed by between -102 and $+11 \mu$ eq $\mathrm{l}^{-1}$ (median $-13 \mu \mathrm{eq} \mathrm{l}^{-1}$ ). The increase in organic acidity is thus of a similar magnitude to the decrease in mineral acidity. Together with observed reductions in labile $\mathrm{Al}$ at many sites, this explains why ANC has increased significantly at many sites, but alkalinity has not (Table 2, Fig. 4). In effect, this replacement of mineral by organic acidity represents a 'confounding factor' with regard to recovery from acidification in the UK although it must be emphasised that this replacement has only been partial, since reductions in $\mathrm{H}$ and labile $\mathrm{Al}$ have also occurred. Furthermore, the change in $\mathrm{Al}$ speciation from labile to non-labile forms will have reduced biological toxicity even at an unchanged $\mathrm{pH}$ (Baker et al., 1990).

\section{Conclusions}

The results of this study contrast with those of previous analyses of AWMN data over shorter time periods (Patrick et al., 1995; Stoddard et al., 1999; Monteith and Evans, 2000) in showing for the first time clear and widespread evidence of the onset of recovery from acidification. At many sites, concentrations of $\mathrm{xSO}_{4}$ were lower between 1998 and 2000 than at any time in the preceding decade, confirming a downward trend in pollutant $\mathrm{SO}_{4}$ levels thought to have begun during the mid-1990s. Together with a reduction in the high levels of rainfall and sea-salt deposition observed during the early years of monitoring, this appears to have resulted in a general reduction in acidity and toxic labile $\mathrm{Al}$ concentrations and an increase in ANC. As would be expected, trends are strongest at highly acidified sites closer to emissions sources and weakest at sites in remote, 
unimpacted regions. Trends are generally clearest in lakes, but many of the same trends, particularly changes in $\mathrm{xSO}_{4}$, can also be identified at streams despite greater episodicity. Forested sites also show similar $\mathrm{SO}_{4}$ changes to moorland systems but most do not yet show evidence of recovery, possibly due to the continuing depletion of soil base cation stores by forest uptake and enhanced acid deposition.

Reductions in $\mathrm{SO}_{4}$ concentrations, where observed, have been balanced by changes in a range of other solutes. The major changes observed are: (a) decreases in catchmentderived base cations (mainly $\mathrm{Ca}$ ); (b) increases in organic acids; and (c) reductions in acidity ( $\mathrm{H}$ and labile $\mathrm{Al})$. In effect, both (a) and (b) can be considered 'confounding factors' in that they limit the response of runoff acidity to reductions in acid anion concentrations. Of the two, changes in base cation concentrations are widely recognised as a negative feedback on changes in mineral acid inputs, ameliorating acidification but also slowing recovery. The large observed increases in DOC, and hence organic acidity, are less well understood and a key uncertainty exists as to whether these changes are linked to reductions in mineral acidity (therefore representing a further negative feedback on acidification and recovery) or to climatic changes (thus forming a coincidental, but nonetheless important, counter to reduced mineral acidity in the UK). Two other processes with the potential to limit recovery, increased $\mathrm{N}$ leaching and the long-term release of stored S, have not been clearly demonstrated for AWMN waters.

Finally, climatic fluctuations have a major impact on interannual chemical variations in many solutes, including $\mathrm{SO}_{4}$, $\mathrm{NO}_{3}$, base cations and acidity. Providing that the drivers underlying these fluctuations, such as the NAO, do not alter over the longer term, these variations will be essentially cyclical and should not, therefore, be considered as confounding factors in recovery. Instead, these climatic fluctuations represent an important source of 'noise' in monitoring datasets, potentially on timescales of a decade or more and an understanding of these processes, along with a sufficient period of monitoring, is essential for the accurate identification of underlying trends towards recovery from acidification.

\section{Acknowledgements}

This work has been funded by the United Kingdom Department of the Environment, Transport and the Regions (Contract No. EPG 1/3/92), the Environment and Heritage Service, Northern Ireland, and by the Commission of European Communities RECOVER:2010 project (EVK1CT-1999-00018).

\section{References}

Aber, J.D., Nadelhofer, K.J., Streudler, P. and Melillo, J., 1989. Nitrogen saturation in northern forest ecosystems. BioScience, 39, 378-386.

Baker, J.P., Bernard, D.P., Christensen, S.W. and Sale, M.L., 1990. Biological effects of changes in surface water acid-base chemistry. In: Acid Deposition: State of Science and Technology, NAPAP Report 9, National Acid Precipitation Assessment Program, Washington, D.C.

Battarbee, R.W., Anderson, N.J., Appelby, P.G., Flower, R.J., Fritz, S.C., Haworth, E.Y., Higgitt, S., Jones, V.J., Munro, M.A.R., Natkanski, J., Oldfield, F., Patrick, S.T., Richardson, N.G., Rippey, B. and Stevenson, A.C., 1988. Lake acidification in the UK 1800-1986: evidence from the analysis of lake sediments. ENSIS Publishing, London.

Campbell, G., Vincent, K., Downing, C., Hasler, S., Donovan, B., Smith, M., Sansom, L. and Page, H., 1998. Acid Deposition Monitoring in the UK: 1986 to 1997. Report to the Department of the Environment, Transport and the Regions, AEA Technology, Culham, Oxon, UK.

Driscoll, C.T., Baker, J.P., Bisogni, J.J. and Schofield, C.L., 1984. Aluminum speciation and equilibria in dilute acidic surface waters of the Adirondack region of New York State. In: Geological Aspects of Acid Deposition, O.P. Bricker (Ed.) . Butterworth, Boston, USA.

Evans, C.D. and Monteith, D.T., 2001. Natural and anthropogenic changes in the chemistry of six UK mountain lakes, 1988 to 2000. Water Air Soil Pollut., (in press).

Evans, C.D., Monteith, D.T. and Harriman, R., 2001a. Long-term variability in the deposition of marine ions at west coast sites in the UK Acid Waters Monitoring Network: Impacts on surface water chemistry and significance for trend determination. Sci. Total Envir., 265, 115-129.

Evans, C.D., Cullen, J.M., Alewell, C., Kopácek, J., Marchetto, A., Moldan, F., Prechtel, A., Rogora, M., Veselý, J. and Wright, R.F., 2001b. Recovery from acidification in European surface waters. Hydrol. Earth Syst. Sci., 5, 283-297.

Evans, C.D., Harriman, R., Monteith, D.T. and Jenkins, A., 2001c. Assessing the suitability of acid neutralising capacity as a measure of long-term trends in acid waters based on two parallel datasets. Water Air Soil Pollut., (in press).

Fowler, D. and Smith, R., 2000. Spatial and temporal variability in the deposition of acidifying species in the UK between 1986 and 1997. In: The UK Acid Waters Monitoring Network: 10 Year Report. Analysis and Interpretation of Results, April 1988 - March 1998, D.T. Monteith and C.D. Evans (Eds.). ENSIS Publishing, London, $363 \mathrm{pp}$.

Freeman, C., Ostle, N. and Kang, H., 2001. An enzymatic 'latch' on a global carbon store. Nature, 409, 149.

Harriman, R. and Morrison, B.R.S., 1982. Ecology of streams draining forested and non-forested catchments in an area of central Scotland subject to acid precipitation. Hydrobiologia, 88, 251-263.

Harriman, R. and Taylor, E.M., 1999. Acid Neutralising Capacity and Alkalinity: Concepts and Measurement. Report SR (99) 06F, Freshwater Fisheries Laboratory, Pitlochry, 14 pp.

Harriman, R., Christie, A.E.G., McCartney, A.G., Moore, D.W., Taylor, E.M., Watson, J. and Watt, A.W., 2001. Interpretation of recovery trends in acidic deposition and surface waters in Scotland over the past three decades. Hydrol. Earth Syst. Sci., 5, 407-420.

Helliwell, R.C., Ferrier, R.C., Johnson, L. and Goodwin, J., 2001. Land use influences on acidification and recovery of freshwaters in Galloway, south-west Scotland. Hydrol. Earth Syst. Sci., 5, $451-458$. 
Hirsch, R.M. and Slack, J.R., 1984. A nonparametric test for seasonal data with serial dependence. Water Resour. Res., 20 , $727-732$.

Hirsch, R.M., Slack, J.R. and Smith, R.A., 1982. Techniques of trend analysis for monthly water quality data. Water Resour. Res., 18, 107-121.

Hurrell, J.W., 1995. Decadal trends in the North Atlantic Oscillation, regional temperatures and precipitation. Science, 269, 676-679.

Jenkins, A., Renshaw, M., Helliwell, R., Sefton, C., Ferrier, R. and Swingewood, P., 1997. Modelling surface water acidification in the UK. IH Report 131, Wallingford, UK. 53 pp.

Kalbitz, K., Solinger, J-H., Park, B., Michalzik, B. and Matzner, E., 2000. Controls on the dynamics of dissolved organic matter: a review. Soil Sci., 165, 277-304.

Kernan, M.R. and Allott, T.E.H., 1999. Spatial variability of nitrate concentrations in lakes in Snowdonia, North Wales, UK. Hydrol. Earth Syst. Sci., 3, 395-408.

Krug, E.C. and Frink, C.R., 1983. Acid rain on acid soil: A new perspective. Science, 221, 520-525.

Langan, S.J., 1989. Sea-salt induced streamwater acidification. Hydrol. Process., 3, 25-41.

Mayer, R. and Ullrich, B., 1977. Acidity of precipitation as influenced by the filtering of atmospheric $\mathrm{S}$ and $\mathrm{N}$ compounds - its role in the element balance and effect on soil. Water, Air, Soil Pollut., 9, 409-416.

Miller, H.G., 1981. Forest fertilisation: Some guiding concepts. Forestry, 54, 157-167.

Monteith, D.T. and Evans, C.D. (Eds.), 2000. The UK Acid Waters Monitoring Network: 10 Year Report. ENSIS Publishing, London, 363 pp.

Monteith, D.T., Evans, C.D. and Reynolds, B., 2000. Evidence for a link between temporal variations in the nitrate content of UK upland freshwaters and the North Atlantic Oscillation. Hydrol. Process., 14, 1745-1749.

Neal, C., Whitehead, P.G., Neale, R. and Cosby, B.J., 1986. Modelling the effects of acidic deposition and conifer afforestation on stream acidity in the British Uplands. J. Hydrol., 86, 15-26.
Neal, N., Reynolds, B. and Robson, A.J., 1999. Acid neutralising capacity measurements within natural waters: towards a standardised approach. Sci. Total. Envir., 243, 233-241.

NEGTAP, 2001. Transboundary Air Pollution: Acidification, Eutrophication and Ground-level Ozone in the UK. $1^{\text {st }}$ Report of the National Expert Group on Transboundary Air Pollution. UK Department of the Environment, Transport and the Regions, London, (in press).

Patrick, S.T., Monteith, D.T. and Jenkins, A., 1995. UK Acid Waters Monitoring Network: The first five years. Analysis and interpretation of results, April 1988-March 1993. ENSIS Publishing, London, $320 \mathrm{pp}$.

Reuss, J.O., Christophersen, N. and Seip, H.M., 1986. A critique of models for freshwater and soil acidification. Water Air Soil Pollut., 30, 909-930.

Sen, P.K., 1968. Estimates of the regression coefficient base on Kendall's Tau. J. Amer. Statis. Assn., 63, 1379-1389.

Stoddard, J., 1994. Long-term changes in watershed retention of nitrogen. In: Environmental Chemistry of Lakes and Reservoirs, L.A. Baker. (Ed.), 223-284. American Chemical Society.

Stoddard, J.L., Jeffries, D.S., Lükewille, A., Clair, T.A., Dillon, P.J., Driscoll, C.T., Forsius, M., Johannessen, M., Kahl, J.S., Kellogg, J.H., Kemp, A., Mannio, J., Monteith, D.T., Murdoch, P.S., Patrick, S., Rebsdorf, A., Skjelkvåle, B.L., Stainton, M.P., Traaen, T., van Dam, H., Webster, K.E., Wieting, J. and Wilander, A., 1999. Regional trends in aquatic recovery from acidification in North America and Europe. Nature, 401, 575578.

Tipping, E. and Hurley, M.A., 1988. A model of solid-solution interactions in acid organic soils, based on the complexation properties of humic substances. J. Soil Sci., 39, 505-519.

Wright, R.F., Norton, S.A., Brakke, D.F. and Frogner, T., 1988. Experimental verification of episodic acidification of freshwaters by sea salts. Nature, 334, 422-424.

Wright, R.F., Alewell, C., Cullen, J., Evans, C.D., Marchetto, A., Moldan, F., Prechtel, A. and Rogora, M., 2001. Trends in nitrogen deposition and leaching in acid sensitive streams in Europe. Hydrol. Earth Syst. Sci., 5, 299-310. 